Research Paper

\title{
The anti-tumor efficacy of 3-(2-Nitrophenyl) propionic acid- paclitaxel (NPPA-PTX): a novel paclitaxel bioreductive prodrug
}

\author{
Ping Song ${ }^{2, *}$, Xin Yao $^{1,2, *}$, Ting Zhong ${ }^{1,2}$, Shuang Zhang ${ }^{1,2}$, Yang Guo ${ }^{1,2}$, Wei Ren ${ }^{1,2}$, \\ Dan Huang ${ }^{1,2}$, Xiao-Chuan Duan ${ }^{1,2}$, Yi-Fan Yinn ${ }^{1}$, Shu-Shi Zhang ${ }^{1}$, Xuan Zhang ${ }^{1,2}$ \\ ${ }^{1}$ Beijing Key Laboratory of Molecular Pharmaceutics and New Drug Delivery Systems, School of Pharmaceutical Sciences, \\ Peking University, Beijing 100191, China \\ ${ }^{2}$ Department of Pharmaceutics, School of Pharmaceutical Sciences, Peking University, Beijing 100191, China \\ *These authors have contributed equally to this work \\ Correspondence to: Xuan Zhang, email: xuanzhang@bjmu.edu.cn \\ Keywords: paclitaxel, 3-(2-Nitrophenyl) propionic acid, bioreductive prodrug, tumor hypoxia, anti-tumor efficacy \\ Received: February 15, 2016 \\ Accepted: June 09, 2016 \\ Published: June 27, 2016
}

\section{ABSTRACT}

Hypoxia is an important microenvironmental pressure present in the majority of solid tumors and, so, tumor hypoxia might be considered an attractive target for tumor therapy. One strategy for targeting hypoxia is to develop bioreductive prodrugs. In the present research, we synthesized a bioreductive paclitaxel prodrug, 3-(2-Nitrophenyl) propionic acid-paclitaxel (NPPA-PTX). The stability of NPPA-PTX in PBS and rat plasma was investigated. The anti-tumor activity of NPPA-PTX was also evaluated in vitro and in vivo. The results of our stability study indicated that NPPA-PTX was stable in PBS and rat plasma as well as in the blood circulation. The in vitro and in vivo anti-tumor activity of NPPA-PTX was confirmed in both KB cells and MDA-MB-231 cells. Our results also indicated that NPPA-PTX could completely convert to active PTX in tumor tissues and produced the anti-tumor activity in both KB and MDA-MB-231 tumor-bearing nude mice. We suggest that the dissociated PTX which converted from NPPA-PTX in tumor tissues played a key role in producing anti-tumor activity. Considering all our results, we suggest that NPPA-PTX is a novel bioreductive PTX prodrug which could undergo further evaluation.

\section{INTRODUCTION}

Hypoxia is a common feature of most tumors because of the limited oxygen diffusion and highly abnormal tumor microvasculature [1-3]. It is a negative factor owing to its multiple contributions to a variety of phenomena such as chemo/radio-resistance, angiogenesis, and metastasis. Also, hypoxic tumor cells exhibit a greater capacity for reductive reactions compared with normal well-oxygenated cells [4-5]. Therefore, tumor hypoxia is an attractive target for tumor therapy [1]. One strategy for targeting hypoxia is to develop bioreductive prodrug that is activated by enzymatic reduction in hypoxic tissue [6-7]. To date, five distinct types of bioreactive prodrugs, including nitro groups, quinones, aromatic $\mathrm{N}$-oxides, aliphatic $\mathrm{N}$-oxides and transition metals, have been developed for targeting hypoxic cells in solid tumors [1]. Several examples including PR-104, TH-302, and EO9 are reported to be undergoing phase II/III clinical evaluation [8-9].
Nitrophenylalkanoic acid is reported to target hypoxic region of solid tumors as shown in early radio therapeutic enhancement in vivo [10]. Its derivatives tend to be nontoxic or only weakly toxic in normal tissues but become activated in hypoxic tumor tissues [11-12]. Introduction of nitrophenylalkanoic acid to form conjugate with conventional chemotherapeutic drug is relatively simple and the produced prodrug tends to exhibit specific selectivity for hypoxic tumor tissues [13-14]. The nitro group of the prodrug is assumed to be reduced under reducing conditions, thereby undergoing subsequent activation through intramolecular cyclization to release the parent drug [15]. In addition, some research has proposed that the activation process tends to be triggered in an acidic environment, which suggests that it is more likely to be reduced at a low $\mathrm{pH}$ in tumor tissues [16].

Paclitaxel (PTX) is one of the most successful anticancer drugs in clinical use, and it exhibits high antitumor efficacy against a wide range of tumors [17-18]. As 
the free 2 -hydroxyl group is an important active part of PTX structure, it is easier to introduce other groups at the $2^{\prime}$-position to obtain a prodrug with little or no potency in the normal internal environment while being activated in tumor tissues [19]. There are many examples of the use of this chosen strategy, but they could not achieve valid release at the disease site or were released too early in circulation [20-21].

In the present study, we conjugated PTX with 3-(2-nitrophenyl)propionic acid (NPPA) at the 2'-hydroxyl group of PTX to produce a novel bioreductive PTX prodrug (NPPA-PTX) which could remain intact and stable in normoxia but be activated in hypoxic tumor tissues. The anti-tumor activity of NPPA-PTX was investigated in vitro and in vivo.

\section{RESULTS}

As shown in Figure 1A, the nitro group of nitrophenylalkanoic acid bioreductive prodrugs may undergo a convertible reduction via $1 \mathrm{e}^{-}$addition in the presence of oxygen, but an irreversible reduction occurred without oxygen. Then, these bioreductive prodrugs continue to be reduced gradually into hydroxy-amine or amino derivatives, thereby releasing PTX through intramolecular cyclization. The structure and molecular formula of NPPA-PTX are shown in Figure 1B and 1C. Our MALDI-TOF spectrum of NPPA-PTX indicate that PTX was successfully conjugated with NPPA (data not shown).

Because the ester linkage in the NPPA-PTX molecule might be susceptible to hydrolysis, the stability of NPPA-PTX is an important issue. The in vitro stability of NPPA-PTX was investigated in PBS and rat plasma. Our results indicated that NPPA-PTX was stable in PBS solution for at least 24 hours without dissociation of PTX from the NPPA-PTX, as shown in Figure 2A. Our results also indicated that NPPA-PTX was also stable in rat plasma at least 24 hours with less than $4.2 \%$ dissociated PTX (Figure 2B). The enzymolysis of NPPA-PTX was evaluated in vitro. As shown in Figure $2 \mathrm{C}$, we found the dissociated PTX released from NPPA-PTX.

The concentration of NPPA-PTX in plasma was determined after a single intravenous injection of NPPAPTX at a dose equimolar with $5 \mathrm{mg} / \mathrm{kg}$ PTX to SD rats in vivo. We observed that the dissociated PTX released from NPPA-PTX was much lower than that of NPPA-PTX, as shown in Figure 3A, indicating that NPPA-PTX was stable in the blood circulation and might be distributed to the tissues as the intact NPPA-PTX. In fact, the dissociated PTX released from the NPPA-PTX could only be detected occasionally in a couple of rats, which also showed that the NPPA-PTX remained structurally intact in the blood circulation (Figure 3B). As shown in Figure 3A, the most concentration points of NPPA-PTX in plasma were higher than that of PTX. The typical pharmacokinetic parameters of NPPA-PTX and PTX are summarized in Table 1. As shown in Table 1, the values of $\mathrm{AUC}_{0-14}, \mathrm{AUC}_{0 \text {-inf }}, \mathrm{t}_{1 / 2}$, $\mathrm{MRT}_{0-14}$ and $\mathrm{MRT}_{0 \text {-inf }}$ in the NPPA-PTX group were significant higher than that in the Taxol group $(p<0.01)$. As prolonged blood circulation is the driving force for increased tumor targeting, the NPPA-PTX was supposed to show an improved therapeutic efficacy.

In vitro cellular uptake of NPPA-PTX was examined in the $\mathrm{KB}$ and MDA-MB-231 cell lines. As shown in Figure 4A, NPPA-PTX exhibited decreased cellular level in KB cells compared with free PTX after an incubation of 2, 4, and $6 \mathrm{~h}(p<0.01)$. However, the dissociated PTX released from NPPA-PTX was also observed, indicating that the NPPA-PTX could dissociate to active PTX. Similar results were also shown in MDA-MB-231cells (Figure 4B).

The in vitro anti-tumor activity of NPPA-PTX in KB and MDA-MB-231 cells was also evaluated. In the $\mathrm{KB}$ cell line, the calculated $\mathrm{IC}_{50}$ value was found to be $0.33 \pm$ $0.05 \mu \mathrm{M}$ for NPPA-PTX, which was significantly higher than that of free PTX $(0.16 \pm 0.04 \mu \mathrm{M})(p<0.01)$, as shown in Table 2. Similar results were also observed in MDAMB-231 cell line.

The in vitro anti-tumor activity of NPPA-PTX in $\mathrm{KB}$ and MDA-MB-231 cells was also evaluated in the simulative hypoxic condition. In the $\mathrm{KB}$ cell line, the calculated $\mathrm{IC}_{50}$ value was found to be $0.209 \pm 0.033 \mu \mathrm{M}$ for NPPA-PTX, which was significantly higher than that of free PTX $(0.127 \pm 0.014 \mu \mathrm{M})(p<0.01)$, as shown in Table 2. Similar results were also observed in MDAMB-231 cell line.

In the simulative hypoxic condition, the $\mathrm{IC}_{50}$ values of NPPA-PTX in KB or MDA-MB-231 cell lines, unlike PTX, were significant lower than that in normal condition, indicating the reduction of NPPA-PTX in the simulative hypoxic condition, as shown in Table 2.

The dissociated PTX from NPPA-PTX in tumor tissues was detected after a single intravenous injection of NPPA-PTX at a dose equimolar with $15 \mathrm{mg} / \mathrm{kg}$ PTX to KB or MDA-MB-231 tumor-bearing nude mice, respectively. As shown in Figure 5B, the dissociated PTX in the KB tumor tissues was detected at $1 \mathrm{~h}$ as well as 4 and $8 \mathrm{~h}$. Compared with the free PTX in KB tumor tissues in the Taxol treatment group (Figure 5A), the dissociated PTX in the NPPA-PTX treatment group was 0.7-, 1.9- and 3.2-fold compared with that in Taxol treatment group at 1, 4 and 8 $h$. We also examined the level of NPPA-PTX in KB tumor tissues after administration of NPPA-PTX (Figure 5B). Compared with the free PTX in tumor tissues in the Taxol treatment group, the level of NPPA-PTX was significantly lower than that of free PTX. At $8 \mathrm{~h}$, no NPPA-PTX was detected in the KB tumor tissues, indicating that NPPAPTX was completely transformed into dissociated PTX. Similar results were observed in MDA-MB-231 tumorbearing nude mice tumor tissues (Figure 5C and 5D). The dissociated PTX in the NPPA-PTX treatment group 
A

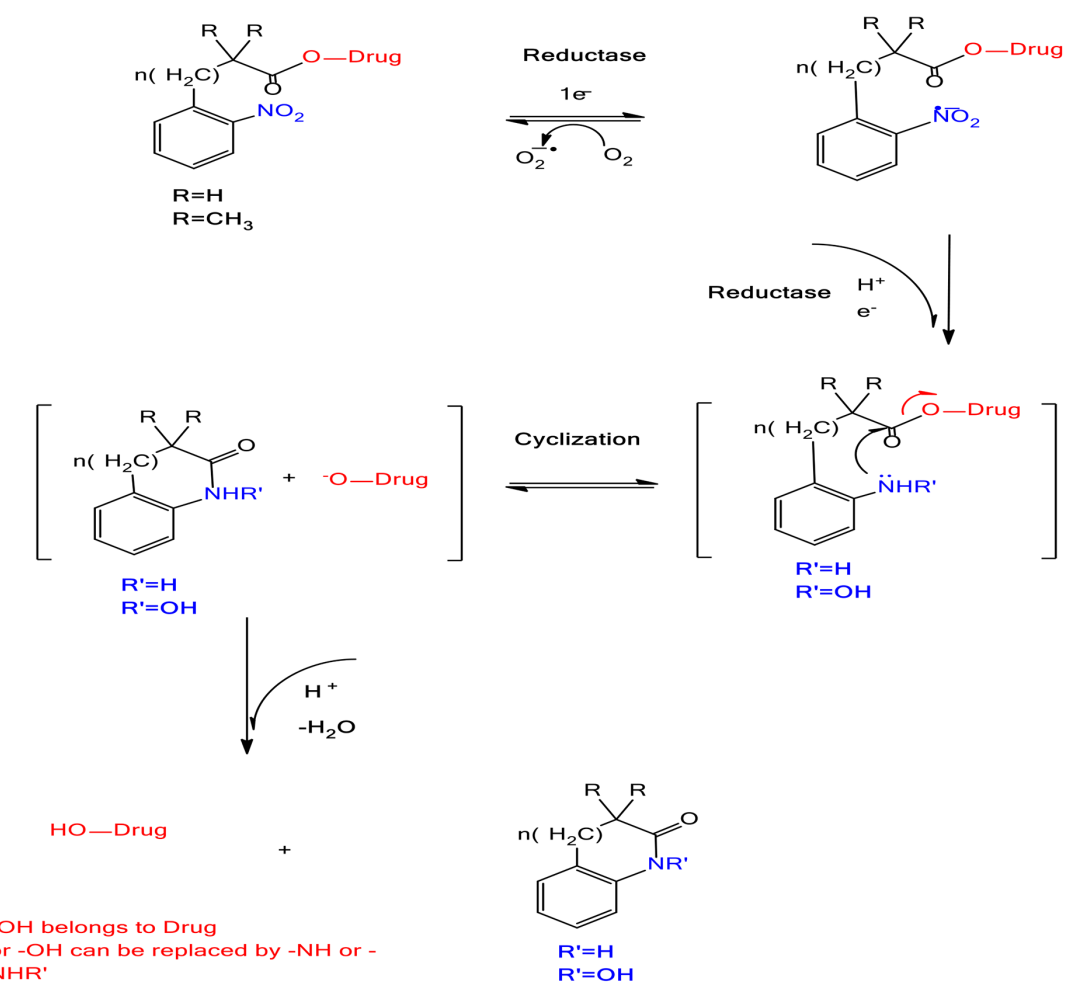

$\mathrm{B}$

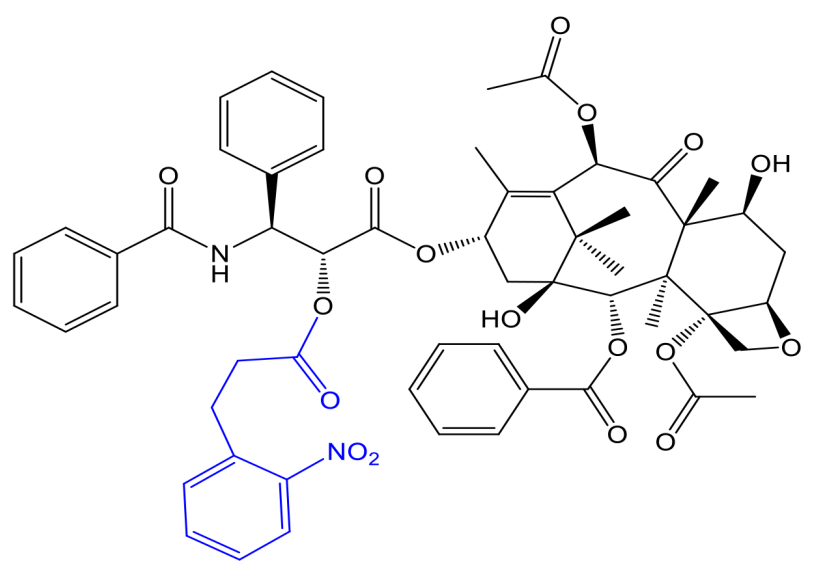

\section{NPPA-PTX}

C

\section{Component}

NPPA

PTX

NPPA-PTX

\section{Molecular formula}

\section{Molecular weight}

195

854

1031

Figure 1: Proposed activation mechanism of nitrophenylalkanoic acid bioreductive prodrugs under convertible reduction. (A). Structures and molecular formulas of NPPA-PTX (B and C). 

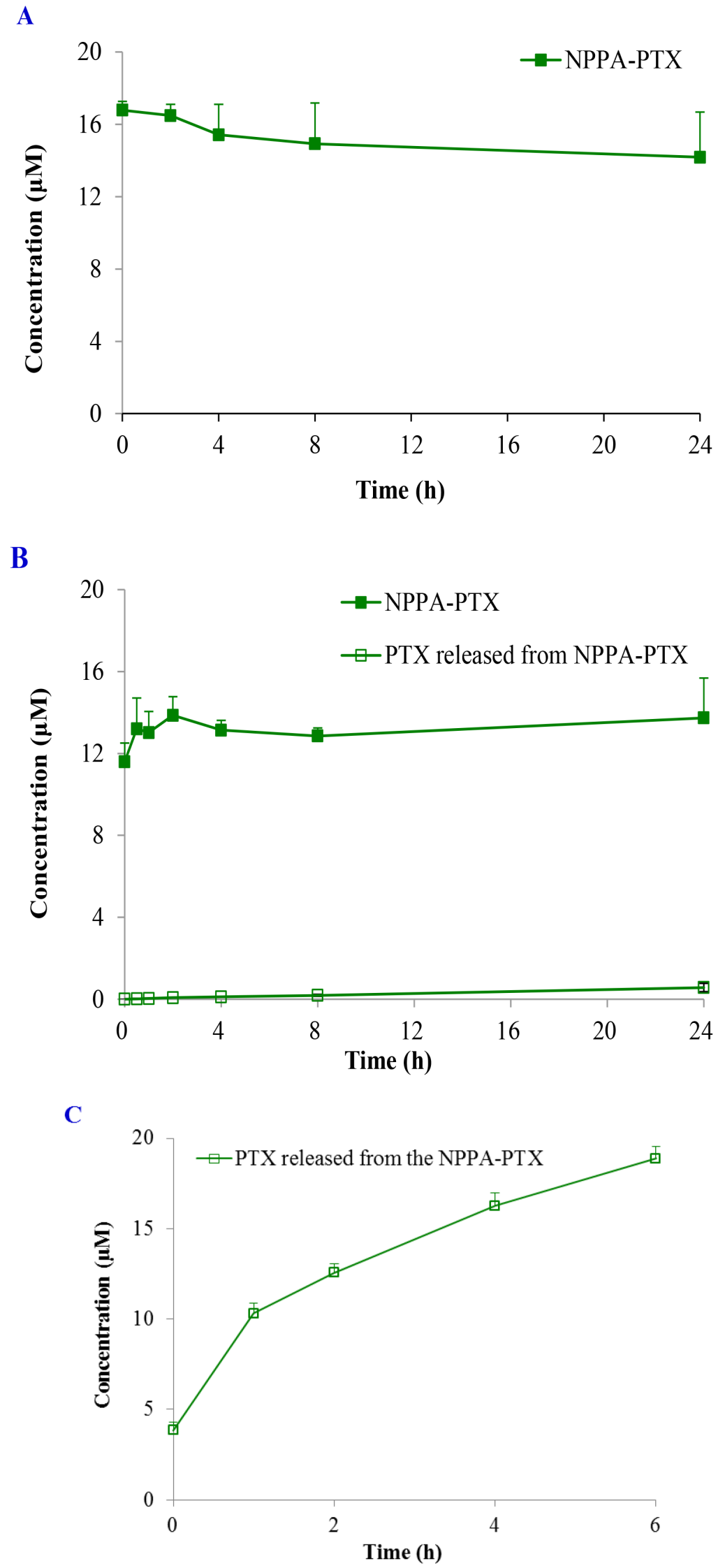

Figure 2: The stability of NPPA-PTX in PBS, rat plasma or incubated with nitroreductase. The stability of NPPA-PTX in PBS at $37^{\circ} \mathrm{C}$. (A); in rat plasma at $37^{\circ} \mathrm{C}(\mathbf{B})$; incubated with nitroreductase at $37^{\circ} \mathrm{C}(\mathbf{C})$. 


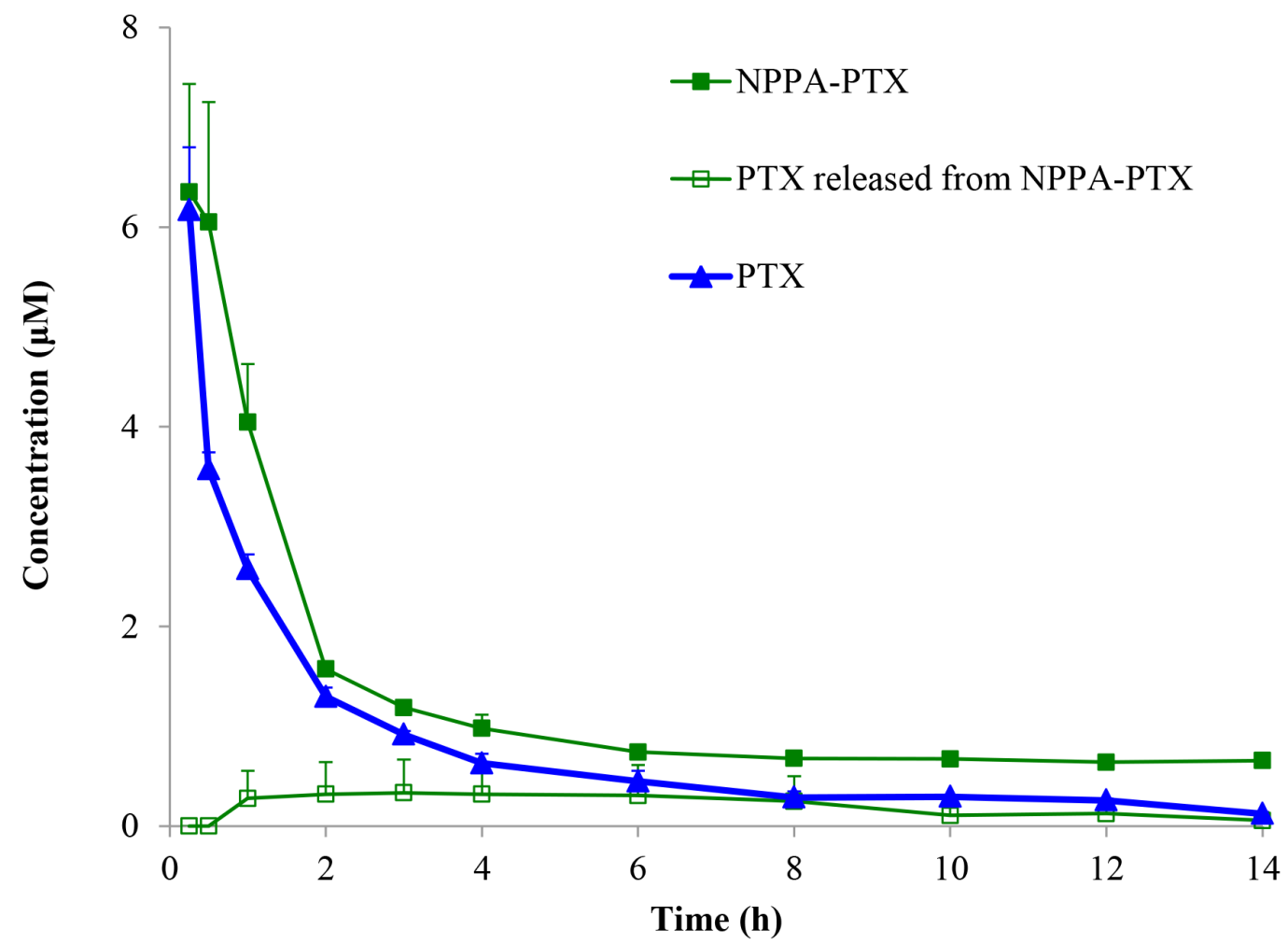

B

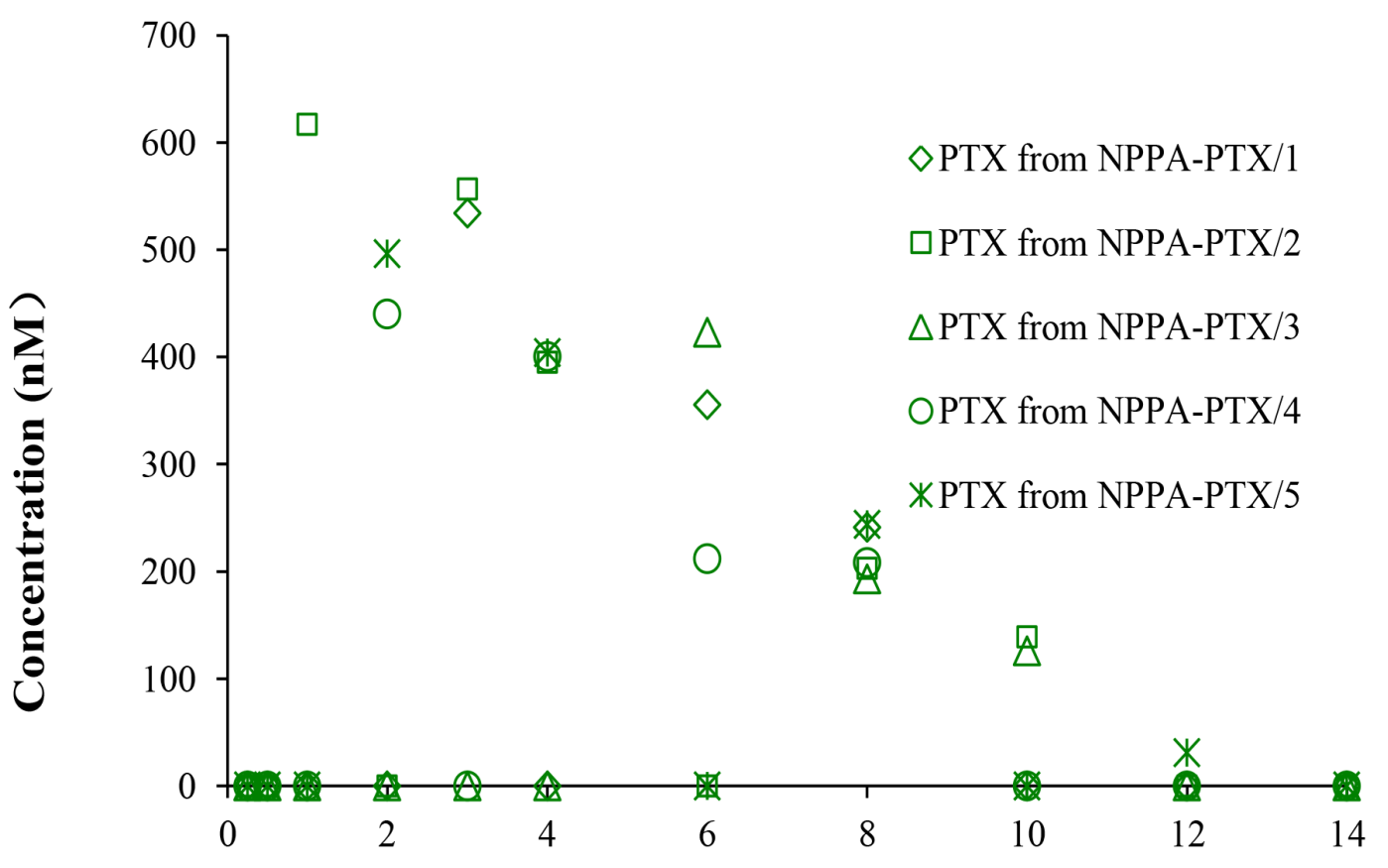

Time (h)

Figure 3: Plasma concentration profiles of NPPA-PTX, dissociated PTX released from NPPA-PTX and PTX. Plasma concentration profiles of NPPA-PTX, dissociated PTX released from NPPA-PTX and PTX after a single intravenous administration of NPPA-PTX at $6.04 \mathrm{mg} / \mathrm{kg}$ (equimolar with $5 \mathrm{mg} / \mathrm{kg}$ PTX) or Taxol $($ PTX $5 \mathrm{mg} / \mathrm{kg}$ ) in rats $(\mathrm{n}=5)$. (A). The plasma concentrations of dissociated PTX released from NPPA-PTX in the individuals rat after i.v. injection in rats $(\mathrm{n}=5)(\mathbf{B})$. 
Table 1: The main pharmacokinetic parameters of NPPA-PTX and PTX after intravenous administration of the NPPAPTX (equimolar with $5 \mathrm{mg} / \mathrm{kg}$ PTX) and Taxol (PTX $5 \mathrm{mg} / \mathrm{kg}$ ) in rats (mean \pm S.D., $\mathrm{n}=5$ )

\begin{tabular}{lccc}
\hline Parameters & Unit & PTX & NPPA-PTX \\
\hline $\mathrm{C}_{\max }$ & $\mu \mathrm{M}$ & $6.2 \pm 0.6$ & $6.7 \pm 0.8$ \\
$\mathrm{AUC}_{(0-14)}$ & $\mu \mathrm{M} * \mathrm{~h}$ & $6.0 \pm 0.5$ & $18.5 \pm 1.5^{* *}$ \\
$\mathrm{AUC}_{0 \text {-inf }}$ & $\mu \mathrm{M} * \mathrm{~h}$ & $6.6 \pm 0.4$ & $40.1 \pm 9.8^{* *}$ \\
$\mathrm{t}_{1 / 2}$ & $\mathrm{~h}$ & $4.6 \pm 1.0$ & $24.4 \pm 9.6^{* *}$ \\
$\mathrm{MRT}_{(0-14)}$ & $\mathrm{h}$ & $3.0 \pm 0.2$ & $3.9 \pm 0.2^{* *}$ \\
$\mathrm{MRT}_{0 \text {-inf }}$ & $\mathrm{h}$ & $4.9 \pm 0.5$ & $28.6 \pm 11.4^{* *}$ \\
$* * p<0.01$ vs PTX group & & &
\end{tabular}

was 0.5 -, 1.4- and 1.5-fold compared with that in Taxol treatment group at 1,4 and $8 \mathrm{~h}$. At 4 and $8 \mathrm{~h}$, no NPPAPTX was detected in the MDA-MB-231 tumor tissues at 4 and $8 \mathrm{~h}$ time points, also indicating that NPPA-PTX was completely transformed into dissociated PTX.

The in vivo anti-tumor activity of NPPA-PTX was evaluated in KB and MDA-MB-231 tumor-bearing nude mice, respectively. As shown in Figure 6A, the tumor growth was significantly inhibited in Taxol and NPPAPTX treatment groups compared with the physiological saline treatment group $(p<0.01)$. Interestingly, NPPAPTX significantly inhibited the growth of KB tumors compared with that in the PTX treatment groups $(p<0.01)$. The average tumor size at day 21 in the PTX and NPPAPTX treatment groups was $331 \pm 56 \mathrm{~mm}^{3}$ and $78 \pm 43 \mathrm{~mm}^{3}$, respectively, compared with $2085 \pm 353 \mathrm{~mm}^{3}$ in the physiological saline group $(p<0.01)$. The corresponding tumor growth inhibition in the PTX and NPPA-PTX -treated groups was about $84 \%$ and $96 \%$.

Similar results were also observed in MDA-MB-231 tumor-bearing nude mice, as shown in Figure 6B. The average tumor size at day 30 in the PTX and NPPAPTX treatment groups was $121 \pm 52 \mathrm{~mm}^{3}$ and $17 \pm 23 \mathrm{~mm}^{3}$, respectively, compared with $1692 \pm 579 \mathrm{~mm}^{3}$ in the physiological saline group $(p<0.01)$. The corresponding tumor growth inhibition in the PTX and NPPA-PTX -treated groups was about $93 \%$ and $99 \%$.

\section{DISCUSSION}

The hypoxic cells could limit the activity of many chemotherapeutic drugs. Nontoxic prodrugs that generate active species in hypoxic tissue by selective bioreduction have long been explored [22].

PTX is one of the most powerful anti-cancer agents currently used in clinic situations. In order to target hypoxic cells in tumors, many bioreductive PTX prodrugs have been investigated [23-26]. These prodrugs were constructed in a manner in which reductive activation, catalyzed by reductive endogenous enzymes, led to PTX release. However, there are few reports about the in vivo anti-tumor activity and bio-distribution in tumor tissues of bioreductive prodrugs. Recently, a PTX bioreductive prodrug which was activated specifically by prostatespecific antigen has been reported [27]. This bioreductive prodrug could be cleaved rapidly releasing the PTXdipeptide, and then degraded to liberate PTX as a final cleavage product within a few hours in prostate tumor tissue. However, the synthetic process of this bioreductive prodrug is more complex and the anti-tumor activity of this bioreative prodrug is comparable with PTX.

It has been reported that nitrophenylacetic acid compounds can be used as triggers for producing bioreductive prodrugs $[10,12,28-29]$. In the present research, we synthesized a novel bioreductive PTX product NPPA-PTX. Our stability results indicated that NPPA-PTX was stable in PBS and rat plasma as well as in the blood circulation.

In the cellular uptake experiment, we observed that NPPA-PTX could partly convert to active parent drug in both KB and MDA-231 cells. We suggested that the in vitro anti-tumor activity of NPPA-PTX was produced by dissociated PTX. In the in vitro simulative hypoxic condition, the anti-tumor activity of NPPA-PTX in KB or MDA-MB-231 cell lines, unlike PTX, were significant higher than that in normal condition, indicating the reduction of NPPA-PTX in the simulative hypoxic condition.

Interestedly, NPPA-PTX was completely converted to active PTX in both KB and MDA-MB-231 tumor tissues. This indicated that the hypoxic microenvironment in the tumor region is one of the most important factors for NNPA-PTX being converted to the parent drug. Because of the concentration of dissociated PTX significantly higher than that of free PTX in both KB and MDAMB-231 tumor tissues, we suggested that the in vivo anti-tumor activity of NPPA-PTX which produced by the dissociated PTX would be higher than that of free PTX in both KB and MDA-MB-231 tumor bearing mice. In addition, our pharmacokinetic results also indicated that NPPA-PTX has a prolonged blood circulation than that of PTX, showing the potential improved therapeutic 


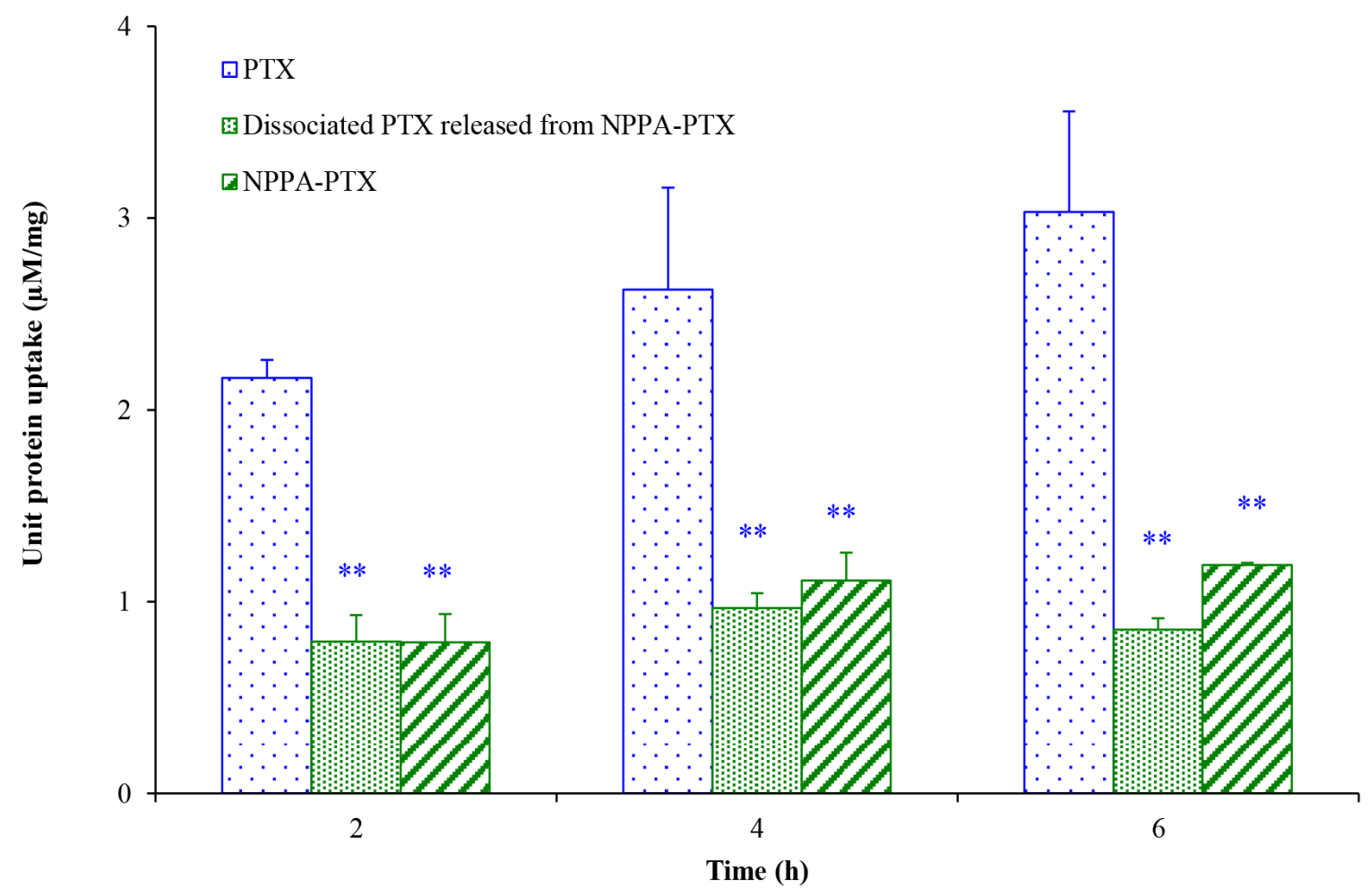

B

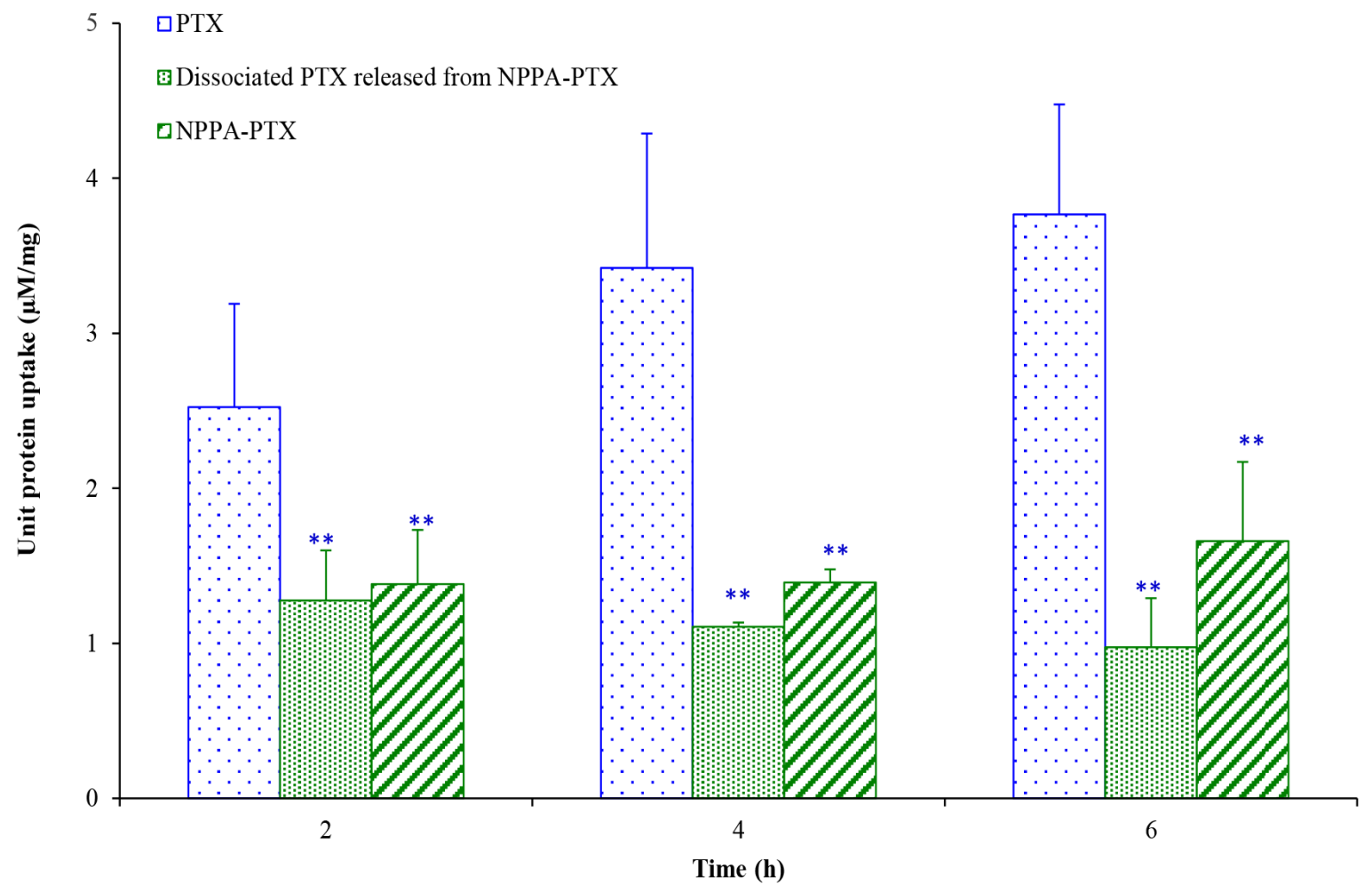

Figure 4: Cell uptake efficiency following culture with PTX and NPPA-PTX for 2, 4, $6 \mathrm{~h}$ in KB cells. (A) and MDAMB-231 cells (B). ${ }^{* *} p<0.01$, compared with PTX group. 
Table 2: IC50 values $(\mu \mathrm{M})$ of NPPA-PTX on KB and MDA-MB-231 cell lines in normal and simulative hypoxic condition

\begin{tabular}{lcccc}
\hline Cell lines & \multicolumn{2}{c}{ Normal condition } & \multicolumn{2}{c}{ simulative hypoxic condition } \\
\cline { 2 - 5 } & \multicolumn{1}{c}{ PTX } & NPPA-PTX & PTX & NPPA-PTX \\
\hline KB & $0.155 \pm 0.035$ & $0.331 \pm 0.048 * *$ & $0.127 \pm 0.014$ & $0.209 \pm 0.033^{* *} \$ \$$ \\
MDA-MB-231 & $1.36 \pm 0.21$ & $3.78 \pm 0.32 * *$ & $1.118 \pm 0.207$ & $1.830 \pm 0.260 * * \$ \$$ \\
\hline
\end{tabular}

** $p<0.01$, compared with PTX group.

$\$ \$ p<0.01$, compared with normal condition.
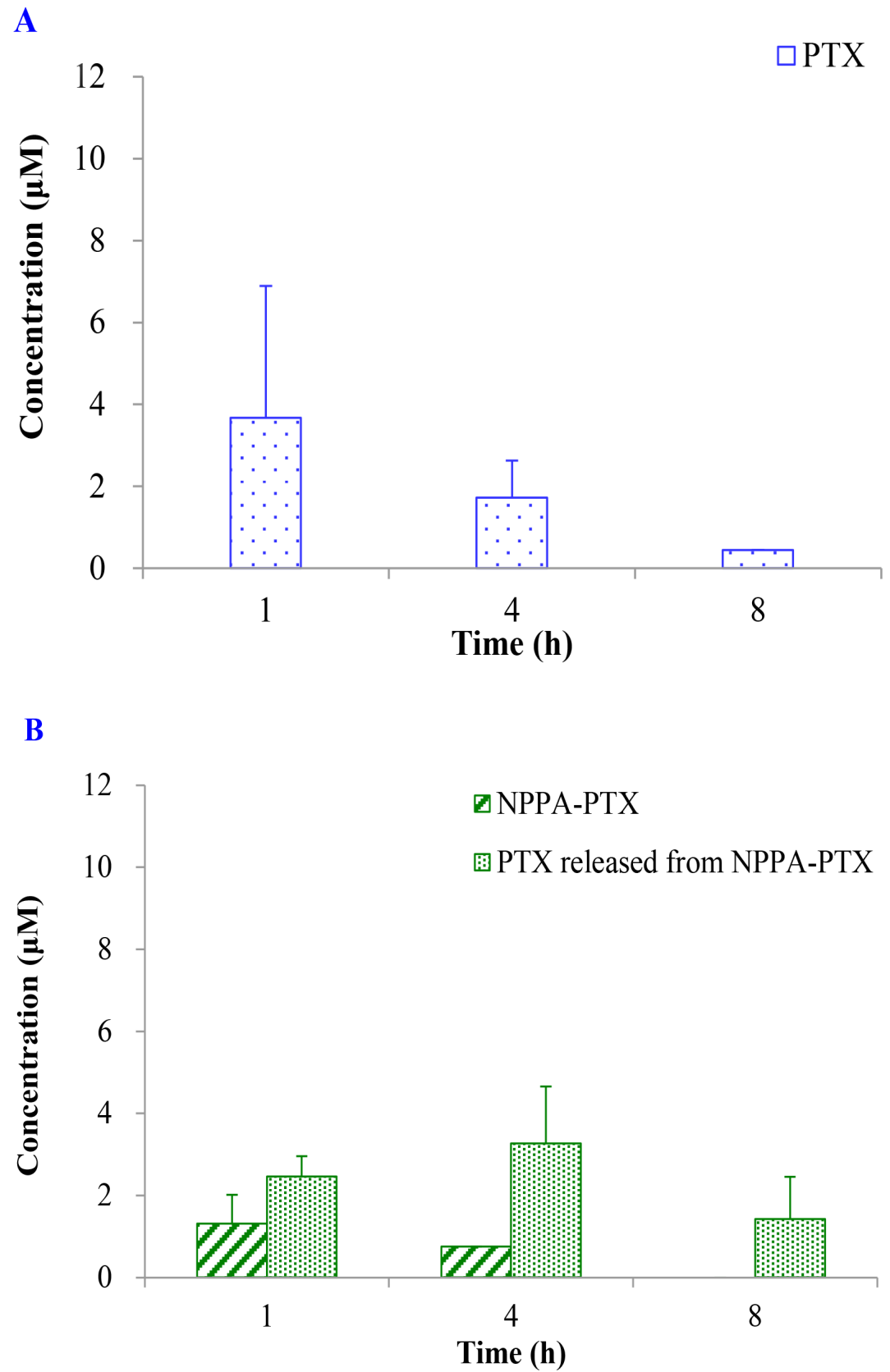

Figure 5: The PTX, NPPA-PTX and PTX released from NPPA-PTX levels $(\mu M)$ in tumor tissues after a single intravenous administration of Taxol at a dose of $15 \mathrm{mg} / \mathrm{kg}$ or NPPA-PTX at a dose of $18.11 \mathrm{mg} / \mathrm{kg}$ (equimolar with 15 $\mathrm{mg} / \mathrm{kg}$ PTX) to KB (A and B) tumor-bearing nude mice. (Mean $\pm \mathrm{SD}$ and $\mathrm{n}=3$ ). 

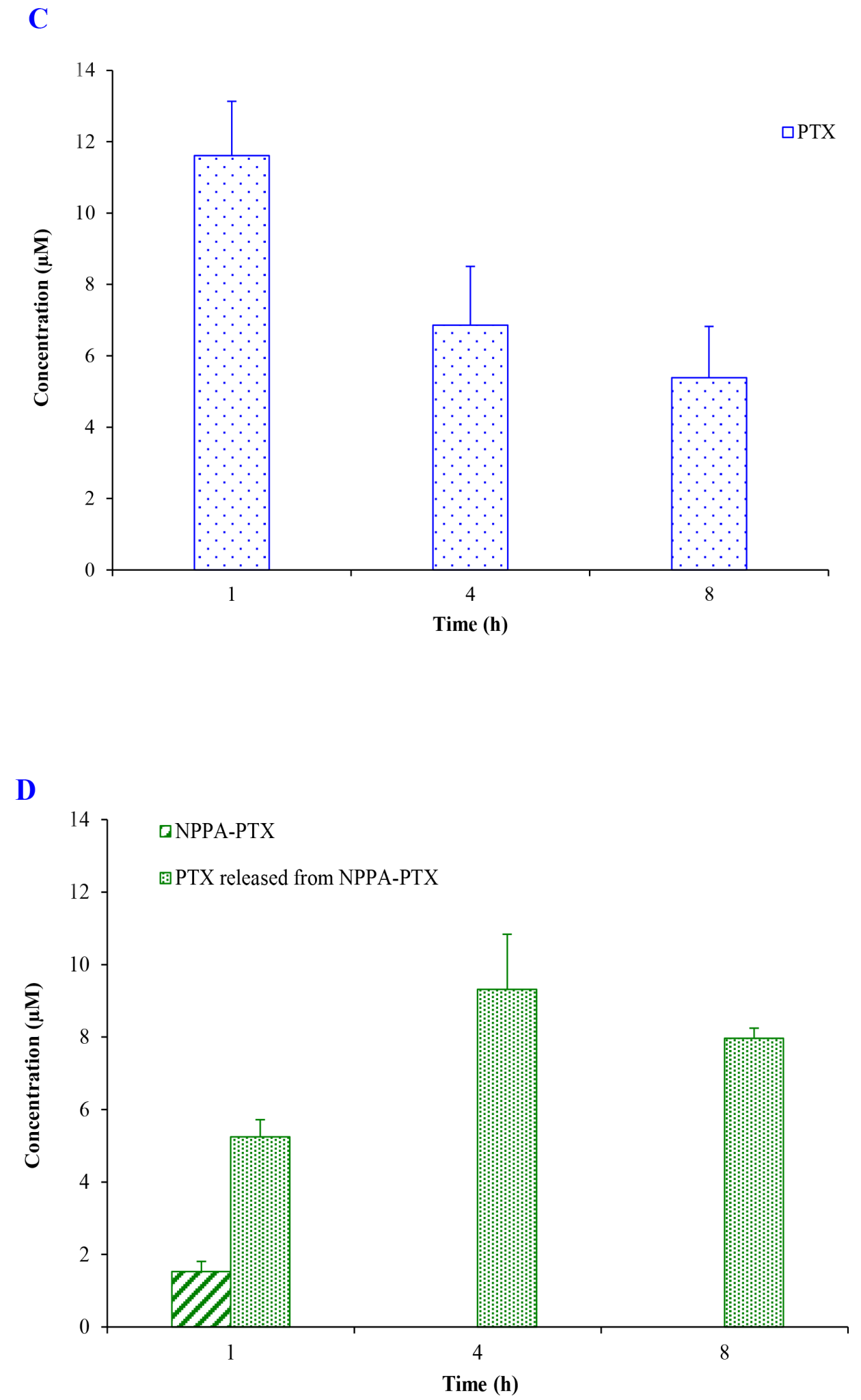

Figure 5: The PTX, NPPA-PTX and PTX released from NPPA-PTX levels $(\mu M)$ in tumor tissues after a single intravenous administration of Taxol at a dose of $15 \mathrm{mg} / \mathrm{kg}$ or NPPA-PTX at a dose of $18.11 \mathrm{mg} / \mathrm{kg}$ (equimolar with 15 mg/kg PTX) to MDA-MB-231 (C and D) tumor-bearing nude mice. (Mean \pm SD and $n=3$ ). 
A

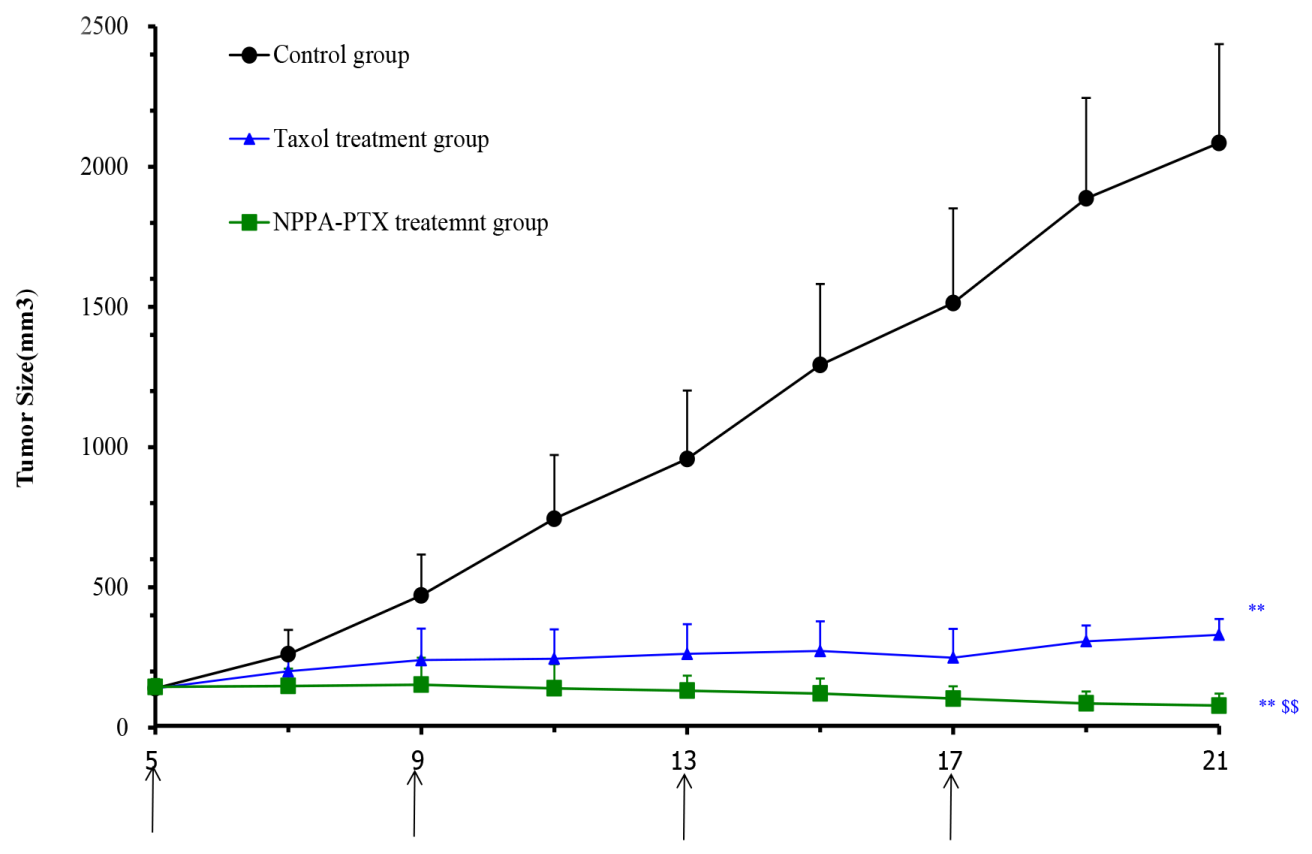

Days after Tumor Inoculation (Day)

B

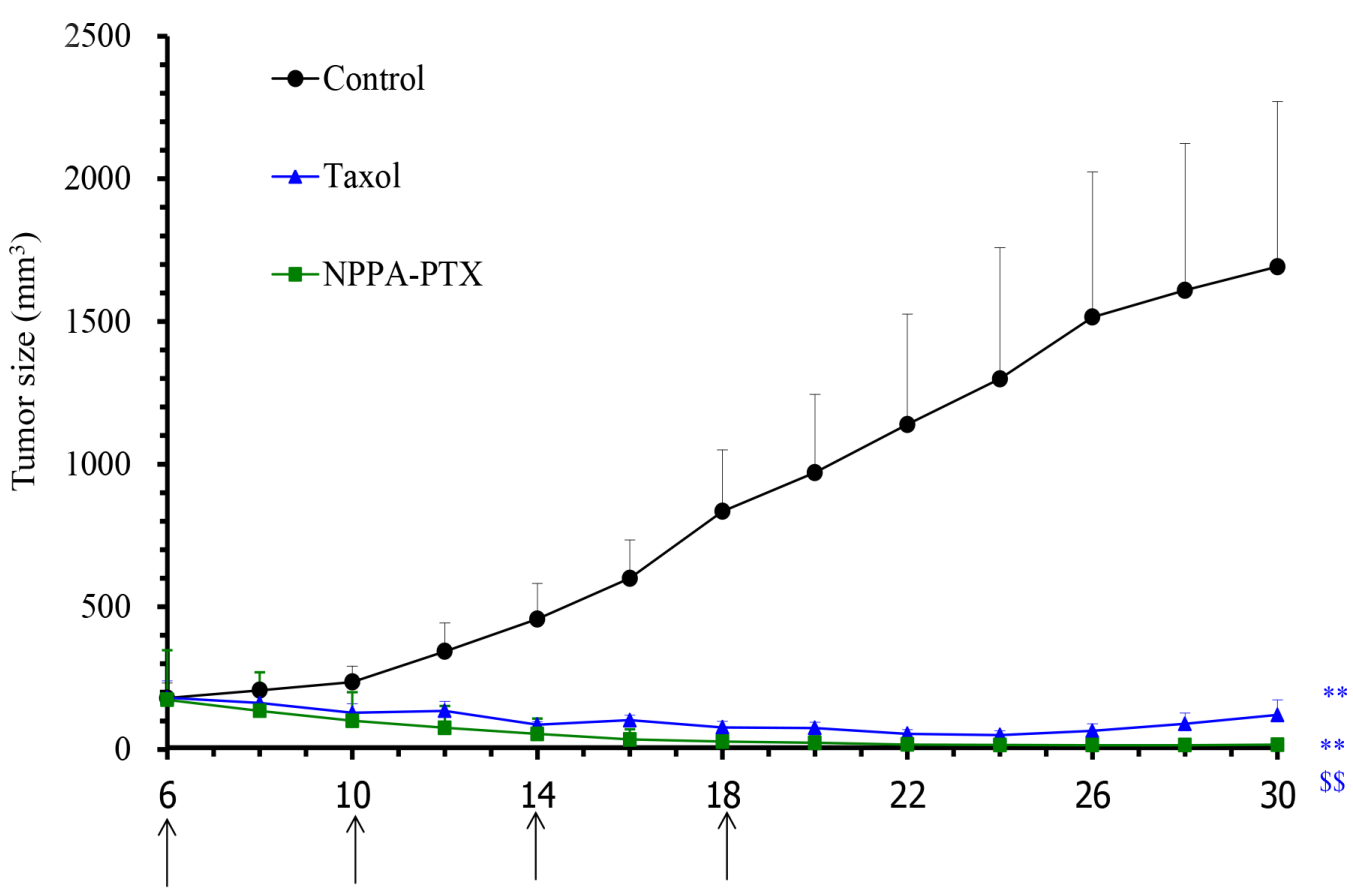

Days after tumor inoculation (day)

Figure 6: In vivo anti-tumor activity of NPPA-PTX in KB (A) and MDA-MB-231 (B) tumor-bearing nude mice. KB cells were implanted in the nude mice on the 0 day, and the treatment was started on the 5th day when the tumor volume reached about 100-200 $\mathrm{mm}^{3}$. The treatment involved administration of saline solution, Taxol and NPPA-PTX on the 5th, 9th, 13rd and 17th day, respectively. Data are presented as the mean $\pm \mathrm{SD}$ per group measured at indicated days after treatment $(\mathrm{n}=6)$. MDA-MB-231 cells were implanted in the nude mice on the 0 day, and the treatment was started on the 6th day when the tumor volume reached about $100-200 \mathrm{~mm}^{3}$. The treatment involved administration of saline solution, Taxol and NPPA-PTX on the 6th, 10th, 14th and 18th day, respectively. Data are presented as the mean $\pm \mathrm{SD}$ per group measured at indicated days after treatment $(\mathrm{n}=6)$. $* * p<0.01$, compared with the control group; $\$ \$ p<0.01$, compared with the Taxol treatment group. 
efficacy. Therefore, we believe that NPPA-PTX was a more effective PTX bioreductive prodrug which could be used for further evaluation.

In summary, we synthesized a novel bioreductive PTX prodrug NPPA-PTX. Our stability results indicated that NPPA-PTX was stable in PBS and rat plasma as well as in the blood circulation. The in vitro and in vivo antitumor activity of NPPA-PTX was confirmed in both KB cells and MDA-MB-231 cells. Our results also indicated that NPPA-PTX could completely convert to active PTX in tumor tissues and produced the anti-tumor activity in both KB and MDA-MB-231 tumor-bearing nude mice. We believe that the dissociated PTX which converted from NPPA-PTX in tumor tissues played a key role in producing anti-tumor activity. Considering all our results, we suggest that NPPA-PTX is a novel bioreductive PTX prodrug which could undergo further evaluation.

\section{MATERIALS AND METHODS}

\section{Materials}

3-(2-Nitrophenyl) propionic acid (NPPA) was obtained from Beijing OUHE Tech. Co. LTD (Beijing, China). N, N'-Dicyclohexylcarbodiimide (DCC), 4-Dime-thylaminopyridine (DMAP) and SRB were all purchased from Sigma-Aldrich (St. Louis, MO, USA). Paclitaxel (PTX) was obtained from Mei-Lian Co., Ltd. (Chongqing, China). Cremophor EL (CrEL) was purchased from BASF Corporation of Germany (Local agent in Shanghai, China). Paclitaxel injection (Taxol) was obtained from a local hospital in Beijing (Bristol Myers Squibb Co., Princeton, NJ, USA). Cell culture media RPMI 1640, penicillin streptomycin, fetal bovine serum, and L-glutamine were obtained from GIBCO, Invitrogen Corp. (Carlsbad, California, USA). Methylene chloride was dehydrated and distilled immediately before use. All other chemicals were of analytical or HPLC grade.

\section{Cell lines}

The KB human mouth oral squamous cell carcinoma (OSSC) cell line was obtained from the Chinese Academy of Sciences Cells Bank (Shanghai, China) and cultivated in RPMI-1640 medium. Each cell culture medium was supplemented with $10 \% \mathrm{FBS}, 100 \mathrm{units} / \mathrm{ml}$ penicillin and $100 \mu \mathrm{g} / \mathrm{ml}$ streptomycin. The cultures were maintained at $37^{\circ} \mathrm{C}, 95 \%$ relative humidity and $5 \% \mathrm{CO}_{2}$.

The MDA-MB-231 cell lines, a human breast cancer cells (ER negative), was obtained from the Chinese Academy of Sciences Cells Bank (Shanghai, China) and cultivated in L-15 medium which was supplemented with $10 \%$ FBS, 100 units $/ \mathrm{ml}$ penicillin and $100 \mu \mathrm{g} / \mathrm{ml}$ streptomycin. The cultures were maintained at $37^{\circ} \mathrm{C}, 95$ $\%$ relative humidity.

\section{Synthesis of NPPA-PTX}

Briefly, PTX (70 mg, $82 \mathrm{mmol}$ ) was dissolved in anhydrous methylene chloride (5 ml), and then NPPA (10 $\mathrm{mg}, 82 \mathrm{mmol})$ and DCC (33.8 $\mathrm{mg}, 164 \mathrm{mmol})$ were added. The reaction mixture was stirred at room temperature for $24 \mathrm{~h}$. The residue was evaporated under nitrogen and then separated by thin-layer chromatography using methylene chloride/methanol (20:1) as the developing solvent. The silica gel which adsorbed the target product was collected and shaken with ethyl acetate then dried under vacuum to obtain the final product (white powder). The purity of NPPA-PTX was $99.7 \%$ (analyzed by HPLC). The structure of NPPA-PTX was characterized by mass spectrometry (MALDI-TOF-MS instrument).

\section{Stability of NPPA-PTX in PBS and rat plasma}

The NPPA-PTX was dissolved in PBS (pH 7.4) at a final concentration of $20 \mu \mathrm{M}$ and incubated at $37^{\circ} \mathrm{C}$ with gentle shaking. Similarly, NPPA-PTX PBS solution was added to rat plasma (the final concentration was $20 \mu \mathrm{g} / \mathrm{ml}$ ) and incubated at $37{ }^{\circ} \mathrm{C}$ with gentle shaking. At scheduled time, samples were analyzed by HPLC as described below to determine the released free PTX. Each experiment was carried out in triplicate.

\section{Nitroreductase assay}

NPPA-PTX was dissolved in $50 \mathrm{mM}$ Tris- $\mathrm{Cl}(\mathrm{pH}$ 7.0) buffer, filtered and degassed for $5 \mathrm{~min}$, to give a final concentration of $1 \mathrm{mM}$. The reaction was carried out anaerobically by repetitive bubbling with nitrogen for 10 $\mathrm{min}$ before and after the addition of nitroreductase. To this solution, nitroreductase and NADPH were added to give final concentrations of $50 \mu \mathrm{g} / \mathrm{ml}$ and $3.4 \mathrm{mM}$, respectively, and incubated at $37^{\circ} \mathrm{C}$. At scheduled times, samples were taken and the reaction stopped by the addition of icecold methanol, and then analyzed by HPLC after being centrifuged at $6000 \mathrm{~g}$ for $5 \mathrm{~min}$. Each experiment was carried out in triplicate.

\section{Stability of NPPA-PTX in rat blood circulation}

SD rats weighing $200 \pm 20 \mathrm{~g}$ were allowed free accessing to standard food and water, maintained on a light/dark cycle under conditions of $25 \pm 3{ }^{\circ} \mathrm{C}$ and $50 \%$ humidity, and allowed to acclimatize for 7 days. All care and handling of animals were performed with the approval of the Institutional Authority for Laboratory Animal Care of Peking University.

The NPPA-PTX solution was prepared using CrEL/ ethanol/saline $(1: 1: 8 \mathrm{v} / \mathrm{v} / \mathrm{v})$ as a solvent. Then, NPPA-PTX solution was injected intravenously into rats at a dose of $6.04 \mathrm{mg} / \mathrm{kg}$ (equimolar with $5 \mathrm{mg} / \mathrm{kg}$ PTX). In addition, Taxol was injected into the tail vein at a single dose of $5 \mathrm{mg} / \mathrm{kg}$. Blood samples $(0.5 \mathrm{ml})$ were collected via the 
orbital venous plexus at $0.25,0.5,1,2,4,6,8,10,12,14$ $\mathrm{h}$ after injection. After centrifugation at $6000 \mathrm{~g}$ for $5 \mathrm{~min}$, the obtained plasma was stored at $-20^{\circ} \mathrm{C}$ until required for HPLC analysis.

Pharmacokinetic parameters were calculated from PTX and NPPA-PTX concentration-time data using noncompartmental methods as implemented by the program WinNonlin version 3.1 (Pharsight Corp., Mountain View, CA, USA). $\mathrm{C}_{\max }$ was the observed values. The AUC was calculated using the linear trapezoidal method and was extrapolated to infinity $\left(\mathrm{AUC}_{\mathrm{inf}}\right)$ by dividing the last measured concentration by the terminal rate constant, $\lambda_{z}$, which was determined from the slope of the terminal phase of the plasma concentration-time curve. The terminal half-life $\left(\mathrm{t}_{1 / 2}\right)$ was calculated as 0.693 divided by $\lambda_{\mathrm{z}}$.

\section{In vitro cellular uptake}

KB cells were seeded in a 6-well flat-bottom tissue-culture plate at a density of $3 \times 10^{5}$ cells/well with $2 \mathrm{ml}$ growth medium. After $24 \mathrm{~h}$, the medium was replaced with NPPA-PTX solution $(10 \mu \mathrm{M})$, and incubated for 2,4 or $6 \mathrm{~h}$ at $37^{\circ} \mathrm{C}$. After incubation, cells were washed twice with cold PBS to remove unbound drug followed by the addition of $200 \mu 10$ $\%$ SDS solution, then $10 \mu \mathrm{l}$ samples were taken for determination of the protein concentration. Following this, the samples were vortexed for $1 \mathrm{~min}$ after addition of $300 \mu \mathrm{l}$ acetonitrile for protein precipitation. A volume of $30 \mu \mathrm{l}$ of supernatant was used for HPLC detection after centrifugation at $6000 \mathrm{~g}$ for $5 \mathrm{~min}$ [30]. For each sample, three wells were measured.

Similarly, MDA-MB-231 cells were seeded respectively in a 6-well flat-bottom tissue-culture plate at a density of $5 \times 10^{5}$ cells/well with $2 \mathrm{ml}$ growth medium, and then proceed as above procedure.

\section{In vitro cytotoxicity}

The in vitro cytotoxicity of NPPA-PTX against KB cells and MDA-MB-231 cells was measured using the SRB method. The KB cells $\left(8 \times 10^{3}\right.$ cells/well $)$ and MDAMB-231 cells $\left(1 \times 10^{4}\right.$ cells/well $)$ were seeded in 96-well plates and incubated for 24 hours, respectively. After that, the cells were treated with different concentrations of NPPA-PTX and incubated for $48 \mathrm{~h}$ at $37{ }^{\circ} \mathrm{C}$. The cell viability was determined by sulforhodamine B assay. Absorbance was measured at $540 \mathrm{~nm}$ using a 96-well plate reader (model 680; Bio-Rad Laboratories, Hercules, CA, USA). The survival percentages were calculated using the formula: survival $\%=(\mathrm{A} 540 \mathrm{~nm}$ for the treated cells $/ \mathrm{A} 540$ $\mathrm{nm}$ for the control cells) $\times 100 \%$, where A540 $\mathrm{nm}$ is the absorbance value. Each assay was carried out in triplicate. Finally, dose-effect curves were constructed and $\mathrm{IC}_{50}$ values were calculated.
The in vitro cytotoxicity of NPPA-PTX in simulative hypoxic condition was also investigated. As same as the above procedure, the cell lines were cultured in simulative hypoxic condition with a modular incubator (MIC 101) and the dual flow meters (one flow is $5 \% \mathrm{CO}_{2}$ and the other flow is $5 \% \mathrm{O}_{2}$ mixed with $90 \% \mathrm{CO}_{2}$.) (BillupsRothenberg, inc. (California, USA)).

\section{Distribution in tumor tissues}

The distribution of NPPA-PTX in tumor tissues was evaluated in $\mathrm{KB}$ and MDA-MB-231 tumor-bearing nude mice. For preparation of the tumor-bearing KB and MDA-MB-231 mice model, briefly, BALB/c nude mice were subcutaneously injected in the right flank with $0.2 \mathrm{ml}$ cell suspension containing $3 \times 10^{6} \mathrm{~KB}$ cells or $1 \times 10^{7} \mathrm{MDA}$ MB-231 cells with $20 \%$ basement membrane matrix, respectively. The BALB/c mice were randomly divided into 2 treatment groups ( 9 mice per group), and the tumors were allowed to grow for 7 days to a volume of $400 \mathrm{~mm}^{3}$. Then, each group was given a tail vein injection of Taxol (15 mg/kg PTX) or NPPA-PTX (18.10 mg/kg, equimolar with $15 \mathrm{mg} / \mathrm{kg}$ PTX). Mice were executed at 1, 4 and 8 $\mathrm{h}$ (each group containing three mice). The tumor tissues were removed and blotted with a paper towel, rinsed in saline, then blotted to remove excess fluid, weighed and stored at $-20{ }^{\circ} \mathrm{C}$ until required for analysis. The tumor tissues were weighed $(1 \mathrm{~g})$ and homogenized with $3 \mathrm{ml}$ PBS, followed by extraction and analysis as described for blood samples.

\section{In vivo anti-tumor efficacy}

The in vivo anti-tumor efficacy of NPPA-PTX was evaluated in KB tumor-bearing nude mice. The BALB/c mice were randomly divided into three groups (6 mice per group), and the tumors were allowed to grow for 5 days to a volume of 100-200 $\mathrm{mm}^{3}$. Then, mice were given an intravenous injection of physiological saline, Taxol or NPPA-PTX at a dose of 15 or $18.10 \mathrm{mg} / \mathrm{kg}$ (equimolar with $15 \mathrm{mg} / \mathrm{kg}$ PTX, q3d×4) through the tail vein. The tumor volume was measured every two days using a calculation based on the equation $\left(a \times b^{2}\right) / 2$, where a and $\mathrm{b}$ are the length and width of the tumor, respectively. The animals were also weighed every two days during the experimental period. After 21 days, all the mice were sacrificed, and the tumor tissues were removed and weighed.

The in vivo anti-tumor efficacy of NPPA-PTX was also evaluated in MDA-MB-231 tumor-bearing nude mice. The BALB/c mice were randomly divided into three groups ( 6 mice per group), and the tumors were allowed to grow for 6 days to a volume of $100-200 \mathrm{~mm}^{3}$. Then, mice were given an intravenous injection of physiological saline, Taxol or NPPA-PTX at a dose of 15 or $18.10 \mathrm{mg} /$ $\mathrm{kg}$ (equimolar with $15 \mathrm{mg} / \mathrm{kg}$ PTX, q3d 34 ) through the 
tail vein. The tumor volume was measured every two days using a calculation based on the equation $\left(a \times b^{2}\right) / 2$, where $a$ and $b$ are the length and width of the tumor, respectively. The animals were also weighed every two days during the experimental period. After 30 days, all the mice were sacrificed, and the tumor tissues were removed and weighed.

\section{HPLC analysis}

NPPA-PTX in plasma was extracted by the following published method with minor modifications [30]. Briefly, plasma $(100 \mu \mathrm{l})$ was mixed with $2.5 \mathrm{ml}$ acetonitrile in a vortex mixer for $1 \mathrm{~min}$. The mixture was then centrifuged at $6000 \mathrm{~g}$ for $5 \mathrm{~min}$, and then 2.0 $\mathrm{ml}$ of supernatant was collected, and dried under a gentle stream of nitrogen at $50{ }^{\circ} \mathrm{C}$ in a water bath. The residue was dissolved in $100 \mu \mathrm{l}$ mobile phase by vortexing and the supernatant $(30 \mu \mathrm{l})$ was injected into the HPLC system. The HPLC system consisted of a Waters 2487 Dual $\lambda$ Absorbance Detector and 1525 pump. An ODS 3C-18 analytical column $(5 \mu \mathrm{m}, 250 \times 4.6 \mathrm{~mm}$, Phenomenex) was used and the wavelength was set at $227 \mathrm{~nm}$. The mobile phase (acetonitrile : water 60:40 v/v) was pumped at a flow rate of $1 \mathrm{ml} / \mathrm{min}$ for $30 \mathrm{~min}$. The retention time of PTX or NPPA-PTX was approximately 7 or $19 \mathrm{~min}$ respectively.

\section{Statistical analysis}

All data are shown as means \pm standard deviation (SD) unless stated otherwise. One-way analysis of variance (ANOVA) was used to determine significance among groups, after which post-hoc tests with the Bonferroni correction were used for comparisons between individual groups. Statistical significance was established at $p<0.05$.

\section{ACKNOWLEDGMENTS AND FUNDING}

The authors gratefully acknowledge the financial support from the National Natural Science Foundation of China (No. 81573360) and the National Basic Research Program of China (973 Program 2013CB932501 and 2015CB932100).

\section{CONFLICTS OF INTEREST}

No potential conflicts of interest were disclosed.

\section{REFERENCES}

1. Wilson WR, Hay MP. Targeting hypoxia in cancer therapy. Nat Rev Cancer. 2011; 11:393-410.

2. Ji RC. Hypoxia and lymphangiogenesis in tumor microenvironment and metastasis. Cancer Lett. 2014; 346:6-16.
3. Hay MP, Hicks KO, Wang J. Hypoxia-directed drug strategies to target the tumor microenvironment. Adv Exp Med Biol. 2014; 772:111-45.

4. Denny WA. The role of hypoxia-activated prodrugs in cancer therapy. Lancet Oncol. 2000; 1: 25-9.

5. Naylor MA, Thomson P. Recent advances in bioreductive drug targeting. Mini Rev Med Chem. 2001; 1:17-29.

6. Guise CP, Mowday AM, Ashoorzadeh A, Yuan R, Lin WH, Wu DH, Smaill JB, Patterson AV, Ding K. Bioreductive prodrugs as cancer therapeutics: targeting tumor hypoxia. Chin J Cancer. 2014; 33:80-86.

7. Bryant JL, Meredith SL, Williams KJ, White A. Targeting hypoxia in the treatment of small cell lung cancer. Lung Cancer. 2014; 86:126-132.

8. McKeage MJ, Gu Y, Wilson WR, Hill A, Amies K, Melink TJ, Jameson MB. A phase I trial of PR-104, a pre-prodrug of the bioreductive prodrug PR-104A, given weekly to solid tumour patients. BMC Cancer. 2011; 11:432.

9. Albertella MR, Loadman PM, Jones PH, Phillips RM, Rampling R, Burnet N, Alcock C, Anthoney A, Vjaters E, Dunk CR, Harris PA, Wong A, Lalani AS, Twelves CJ. Hypoxia-selective targeting by the bioreductive prodrug AQ4N in patients with solid tumors: results of a phase I study. Clin Cancer Res. 2008; 14:1096-104.

10. Chen Y, Hu L. Design of anticancer prodrugs for reductive activation. Med Res Rev. 2009; 29:29-64.

11. Denny WA. Prodrug strategies in cancer therapy. Eur J Med Chem. 2001; 36:577-95.

12. $\mathrm{Hu} \mathrm{L}, \mathrm{Wu} \mathrm{X}$, Han J, Chen L, Vass SO, Browne P, Hall BS, Bot C, Gobalakrishnapillai V, Searle PF, Knox RJ, Wilkinson SR. Synthesis and structure-activity relationships of nitrobenzyl phosphoramide mustards as nitroreductaseactivated prodrugs. Bioorg Med Chem Lett. 2011; 21:3986-91.

13. $\mathrm{Hu}$ L, Liu B, Hacking DR. 5'-[2-(2-Nitrophenyl)-2methylpropionyl]-2'-deoxy-5-fluorouridine as a potential bioreductively activated prodrug of FUDR: synthesis, stability and reductive activation. Bioorg Med Chem Lett. 2000; 10:797-800.

14. Atwell GJ, Sykes BM, O'Connor CJ, Denny WA. Relationships between structure and kinetics of cyclization of 2-aminoaryl amides: potential prodrugs of cyclizationactivated aromatic mustards. J Med Chem. 1994; 37:371-80.

15. Liu B, Hu L. 5'-(2-Nitrophenylalkanoyl)-2'-deoxy-5fluorouridines as potential prodrugs of FUDR for reductive activation. Bioorg Med Chem. 2003; 11:3889-99.

16. Jiang Y, Hu L. N-(2,2-Dimethyl-2-(2-nitrophenyl)acetyl)4-aminocyclophosphamide as a potential bioreductively activated prodrug of phosphoramide mustard. Bioorg Med Chem Lett. 2008; 18:4059-63.

17. Schiff PB, Fant J, Horwitz SB. Promotion of microtubule assembly in vitro by taxol. Nature. 1979; 277:665-7.

18. Wani MC, Taylor HL, Wall ME, Coggon P, McPhail AT. Plant antitumor agents. VI. The isolation and structure of 
taxol, a novel antileukemic and antitumor agent from Taxus brevifolia. J Am Chem Soc. 1971; 93:2325-7.

19. Gu Y, Zhong Y, Meng F, Cheng R, Deng C, Zhong Z. Acetal-linked paclitaxel prodrug micellar nanoparticles as a versatile and potent platform for cancer therapy. Biomacromolecules. 2013; 14:2772-80.

20. Mura S, Zouhiri F, Lerondel S, Maksimenko A, Mougin J, Gueutin C, Brambilla D, Caron J, Sliwinski E, Lepape A, Desmaele D, Couvreur P. Novel isoprenoyl nanoassembled prodrug for paclitaxel delivery. Bioconjug Chem. 2013; 24:1840-9.

21. Zhang SQ, Song YN, He XH, Zhong BH, Zhang ZQ. Liquid chromatography-tandem mass spectrometry for the determination of paclitaxel in rat plasma after intravenous administration of poly(L-glutamic acid)alanine-paclitaxel conjugate. J Pharm Biomed Anal. 2010; 51:1169-74.

22. Denny WA. Hypoxia-activated prodrugs in cancer therapy: progress to the clinic. Future Oncol. 2010; 6:419-28.

23. Vrudhula VM, MacMaster JF, Li Z, Kerr DE, Senter PD. Reductively activated disulfide prodrugs of paclitaxel. Bioorg Med Chem Lett. 2002; 12:3591-4.

24. Skwarczynski M, Hayashi Y, Kiso Y. Paclitaxel prodrugs: toward smarter delivery of anticancer agents. J Med Chem. 2006; 49:7253-69.

25. Damen EW, Nevalainen TJ, van den Bergh TJ, de Groot FM, Scheeren HW. Synthesis of novel paclitaxel prodrugs designed for bioreductive activation in hypoxic tumour tissue. Bioorg Med Chem. 2002; 10:71-7.

26. Wrasidlo W, Gaedicke G, Guy RK, Renaud J, Pitsinos E, Nicolaou KC, Reisfeld RA, Lode HN. A novel 2'-(N-methylpyridinium acetate) prodrug of paclitaxel induces superior antitumor responses in preclinical cancer models. Bioconjug Chem. 2002; 13:1093-9.

27. Elsadek B, Graeser R, Esser N, Schäfer-Obodozie C, Abu Ajaj K, Unger C, Warnecke A, Saleem T, El-Melegy N, Madkor H, Kratz F. Development of a novel prodrug of paclitaxel that is cleaved by prostate-specific antigen: an in vitro and in vivo evaluation study. Eur J Cancer. 2010; 46:3434-44.

28. Zhu R, Liu MC, Luo MZ, Penketh PG, Baumann RP, Shyam K, Sartorelli AC. 4-nitrobenzyloxycarbonyl derivatives of $\mathrm{O}(6)$-benzylguanine as hypoxia-activated prodrug inhibitors of O(6)-alkylguanine-DNA alkyltransferase (AGT), which produces resistance to agents targeting the O-6 position of DNA guanine. J Med Chem. 2011; 54:7720-8.

29. Seow HA, Penketh PG, Shyam K, Rockwell S, Sartorelli AC. 1,2-Bis(methylsulfonyl)-1-(2-chloroethyl)-2-[[1-(4nitrophenyl)ethoxy]carbonyl]hydrazine: an anticancer agent targeting hypoxic cells. Proc Natl Acad Sci U S A. 2005; 102:9282-7.

30. Ke XY, Zhao BJ, Zhao X, Wang Y, Huang Y, Chen XM, Zhao BX, Zhao SS, Zhang X, Zhang Q. The therapeutic efficacy of conjugated linoleic acid - paclitaxel on glioma in the rat. Biomaterials. 2010; 31:5855-64. 